\title{
Scoping Review of Flipped Learning in Engineering Education
}

\section{Abeer Rasheed}

Self-Development Department, Deanship of Preparatory Year \& Supporting Studies, Imam Abdulrahman bin Faisal University, Saudi Arabia.

\begin{abstract}
Real opportunity to use digital technology such as flipped learning has been used in several fields, uncovering diverse benefits regarding its usage. Flipped learning make this possible through mixed environments that allow the combination of learning and discussion courses topics. This scoping review presented that there is potential in using flipped learning in education environment. The results from this systematic review provide valuable information regarding to enhance individual learning.
\end{abstract}

Keywords:

Education, flipped learning, scoping review.

Article Received: 18 October 2020, Revised: 3 November 2020, Accepted: 24 December 2020

Literature highlighted several factors impacted people from various age levels (Jdaitawi, Almutawa, Musallam, \& Talafha, 2014; AlMutawa et al., 2014; Maya Panoraman \& Malek, 2011; Ismael et al., 2015; Jdaitawi et al., 2013). The reforms established in higher education has highlighted the importance of the educational model's effectiveness in equipping university studies with the critical thinking and skills that they need to develop their future professions (Jdaitawi, 2020). To be successful, engineering graduates need to fully comprehend principles and practices of engineering, to collaborate in teams, to communicate effectively and to work in risky and uncertain situations (Adamson \& DalingHammond, 2012; Meier, Williams \& Humphreys, 2000). Engineering education trends requires developing both the technical and non-technical skills of students (Male, 2010; Peter, Khoo, Cowie, Scott \& Round, 2017). Educators need to develop curricula to allow the development of such skills among students.

Throughout the past few decades, researchers have been exerting efforts towards determining the drivers of learning success among students at all levels and educators have been attempting to shift from an instructor-focused learning environment to a student-centered one (Bansal et al., 2020). Several learning methods have been adopted and developed in the present times to adapt to the dynamic changes in the society, science and technology (Sojayapan \& Khlaisang, 2018). One of the top and extensively utilized learning methods from technological and pedagogical developments is flipped learning. In the learning and teaching realm, flipped learning is deemed to have significant contributions, while at the same time, it enhances the students' learning outcomes (Jdaitawi, 2020; Rathner \& Schier, 2020; Akcayir \& Akcayir, 2018). In the field of engineering, flipped classroom approach has been evidenced to enhance the performance of students (Jose et al., 2020), their learning experience (Turnbull, 2018) and their learning perceptions and ultimately achieve their satisfaction (Baytiyeh \& Naja, 2017). It has also been proven to be useful in changing the students' study behavior and habits (Nielsen, 2020), and in supporting positive leisure attitudes and connectedness development (Jdaitawi, 2020).

Flipped learning can be defined as the platform that deliver the passive teaching activities online (or through another medium), which the student accesses in his/her own time (homework), whereas active (student centered) learning activities are completed in the classroom (Rathner \& Schier, 2020; Akcayir \& Akcayir, 2018; Vliet, Winnips, \& Brouwer, 2015). Through flipped learning, the teacher is no longer the "speaker" on the podium; instead, the teacher becomes a coordinator for the students (He et al., 2019). Some scholars have described the nature of the 
flipped teaching mode as follows: by blending the strengths of internet-driven instruction outside the classroom (e.g., digital videos, self-regulated learning, online discussions) and face-to-face inside the classroom (e.g., collaborative study, applied problem-solving, instructor and peer engagement), the flipped learning model can effectively increase student engagement, improve student performance and strengthen the development of creative thinking (Eddy \& Hogan, 2014; McLaughlin et al., 2016; He et al., 2019; Persky, \& Pollack, 2010; Persky, \& Pollack, 2011). In the flipped learning context, students can not only selectively watch online videos based on their knowledge levels but also freely replay core and difficult content. In the classroom, teachers and students have sufficient time to conduct face-to-face discussions. Meanwhile, to enhance knowledge integration and application, students are asked to use in-class time for group discussion which can play an important role in improving students' understanding of the key points of the course (He et al., 2019; Vliet, Winnips, \& Brouwer, 2015).

Literature supported that by using flipped learning model, the students are engaged in more complex activities while they can obtain teachers feedback in a timely manner (Thai, De Wever, \& Valcke, 2017). Flipped learning enables teachers to encourage critical thinking in their students, building the capacity for lifelong learning and preparing future graduates for their work-place contexts (Akçayır \& Akçayır, 2018; O’Flaherty \& Phillips, 2015). The flipped classroom pedagogical approach encourages students to work independently to learn basic facts and concepts outside the classroom through varied methods, including reading, completing online education modules, and watching recorded lectures (Connor et al., 2019; Bergmann, Overmyer, \& Wille, 2018; Davies, Dean, \& Ball, 2013). In the current times, the students' interaction and engagement with learning activities have been enhanced by using flipped learning (Thai et al., 2017; He et al., 2019). Based on the flipped learning studies, flipped learning is able to promote teaching and learning results in terms of attitude, critical thinking, independent learning, interest, motivation, engagement, achievement and eventually, the students' satisfaction (Jdaitawi, 2020; Akcayir \& Akcayir, 2018; Connor et al., 2019; Eddy \& Hogan, 2014; McLaughlin et al., 2014; He et al., 2019; Yacout \& Shoha, 2016).

Educators of engineering believe that flipped approach is a revolution in engineering education (Lee et al. 2015). Although its effect on academic performance is not obvious, it could activate students and encourage their interaction in class (Kanelopoulos et al. 2017; Warter-Perez and Dong 2012). However, not every student could benefit from it. Since the flipping requires strong independent-study abilities, especially in the preclass section, active participants seem to profit more from this approach while passive participants might find this strategy useless to their learning (Lee et al. 2015). Evidence from literature shows that flipped learning strategy is capable of enhancing learning experiences and learning activities (Bansal, et al., 2020; Barrat et al., 2018; Helgevold \& Moen, 2015), and although such teaching approaches are clearly invaluable, studies dedicated to them are still lacking and what few there are reported mixed findings as to the intervention's effectiveness (Vliet et al., 2015; Jdaitawi, 2019; Brewer \& Movahedazarhouligh, 2018; Evans et al., 2019). Therefore, more studies are required to examine the flipped learning effectiveness in learning engineering courses in order to establish a systematic literature review on technology use in education fields (Pervalla \& Uzunboylu, 2019; Karabulut, Jaramillo, \& Jahren, 2018). Such systematic reviews are lacking despite their need to determine flipped learning trends effectiveness, particularly in engineering education (Pervalla \& Uzunboylu, 2019; Karabulut, et al., 2018). Thus, in the present study, literature on knowledge-based flipped learning interventions is extended through the analysis of engineering education-dedicated studies using different databases.

Purpose of the Study 
Literature generally focused on the determinant effectiveness of flipped learning strategy in engineering education, with studies presenting an extensive review of flipped learning factors remaining few and far between. In this regard, this study conducts a systematic literature review to identify the flipped learning status in the field of engineering education and it examines categories of analysis for this purpose and flipped learning advantages, limitations, effectiveness in the same context. The analysis of the different categories would stress on the emerging trends, opportunities, challenges and literature extension and visions towards the objectives and outcomes of its future usage. Flipped learning in engineering education is examined on the basis of the following research questions.

1. What are the skills achieved through flipped learning use in the engineering education?

2. What are the most education levels used in flipped learning engineering studies?

3. What are the advantages and challenges related to flipped learning in engineering studies?

\section{Methodology}

The study adopted Arksey and O'Malley (2005) and Kitchenham's (2004) four-tiered systematic review of studies involving the following phases:

1. Identification of research questions - in the first phase, the trends in educational flipped learning studies conducted from 2015 to 2020 in were identified; flipped learning research dedicated to engineering education, 16 studies were selected from the databases and were deemed appropriate for the objectives of the study and the last phrase is required considering the research questions, which read, 1) What are the skills achieved through flipped learning use in the engineering education? (2) At which education level is flipped learning technology most frequently used for engineering students? and 3) What are the advantages and challenges related with flipped learning in engineering education?

\section{Results and Discussion}

To begin with discussion of results, one of the questions formulated for this study reads, "what are the skills achieved through flipped learning assist in engineering field?". The results from the engineering education studies were coded and tabulated in Table 1- the table enumerates the use of flipped learning in the engineering education field. Based on the table, flipped learning technique enhanced various learning skills among engineering students, including their learning outcomes, performance, their attitudes, personal and cognitive skills (José et al., 2020; Nielsen, 2020; Fox-Turnbull, et al., 2018; Baytiyeh \& Naja, 2017; Aqqal et al. 2017). The table indicates that 18 academic skills commonly mentioned in majority of the articles $10(58.80 \%)$, which supports the effectiveness of flipped learning in enhancing engineering learning among students. The number of studies that supported flipped learning contribution to cognitive skills was $3(17.65 \%)$ and was second rank to the most common flipped learning contribution. As for the enhancement of personal skills, 3 studies (17.65\%) found flipped learning to contribute towards it. One study was found to examine the social skills enhancement of students through flipped learning $(5.90 \%)$ wherein flipped learning mode facilitated interaction and collaborative learning among students and enabled them to extensively engage with each other (Hussain et al., 2020). However, the results reported the positive effect of flipped learning mode on various students' skills (Yoon, 2020; Hussain et al., 2020; Gren, 2019; Fung, 2020, Nielsen, 2020; Baughman et al., 2019; Castedo et al., 2018; Jo et al., 2018). The reason behind the result can be link to the importance of technology in the university life as well as flipped learning mode is currently widely used in engineering education. This may be related to the fact that flipped learning mode is attractive to the students as it piques their interests, motivates them and encourages their interaction in the materials, making them pro- 
active during the sessions, and helping them understand the content to achieve successful outcomes (Yoon, 2020; Hussain et al., 2020; Gren, 2019; Fung, 2020, Bielsen, 2020; Baughman et al., 2019; Castedo et al., 2018; Jo et al., 2018). Furthermore, results confirmed that the flipped learning is one of the preferred methods in teaching-learning process, as it evidenced to have positive effects on the student's skills. Moreover, in Zhang et al. (2020) study, the result revealed that flipped learning enhanced students' awareness, participation, satisfaction and that help them in mastering of knowledge. The result supported that implementing flipped learning in the learning process could improve the learners' long-term memory for information and knowledge storage. The result may also attribute to the use of scientific learning procedures in flipped learning that facilitates optimum achievement and understanding of the abstract concepts in the field through changing practices and engage with the materials (Tutrang \& Schnke, 2017), which helps them to gain various skills. Hussain et al. (2020) reported that one effective strategy to maximize active learning approaches in the classroom and enhance student's engagement with their teachers and peers is flipping the classroom. Mavromihales et al. (2020) also reported that flipped learning assist students in improving their learning experiences and leveraging their engagement.

Researchers investigating non-learning outcomes such as social, cognitive, and personal skills have also been evaluated with similar study designs as those looking at students learning outcomes. Specifically, Nielsen et al. (2020) compared students' behaviors and habits of flipped and nonflipped learning classes and found that the flipped classroom mode supported students in changing their habits and behaviors towards engineering courses. In another study Baytiyeh and Naja (2017) used two teaching models and found that flipped learning promoted a deeper, broader perspective on learning, facilities problem solving strategies and improved critical thinking abilities, self-confidence, and teamwork skills. In fact, prior literature (e.g., Clark et al., 2016; Baughman et al., 2019; Baytiyeh \& Naja, 2017) evidenced that flipped learning is a potential tool in engineering learning and is one of the current technologies that has the potential to be included into learning, providing greater information that extends knowledge master and increase student's engagement and cognitive (Hussain et al., 2020; Zhang et al., 2020).

Table 1: A Summary of the Studies Applying Flipped Learning in Engineering Education

\begin{tabular}{|l|l|l|l|}
\hline Skills & Authors & Variable & Finding \\
\hline Academic & Jo et al. 2018 & $\begin{array}{l}\text { Achievement, } \\
\text { participation and } \\
\text { attitudes }\end{array}$ & $\begin{array}{l}\text { increase student's participation, } \\
\text { achievement and interest }\end{array}$ \\
\cline { 2 - 4 } & $\begin{array}{l}\text { Yoon et al., } \\
2020 \\
\text { Learning } \\
\text { engagement and } \\
\text { perceived } \\
\text { achievement }\end{array}$ & $\begin{array}{l}\text { Enhance student's achievement } \\
\text { and engagement }\end{array}$ \\
\cline { 2 - 4 } & $\begin{array}{l}\text { Jose et al., } \\
2020\end{array}$ & $\begin{array}{l}\text { Students } \\
\text { performance }\end{array}$ & Improved students' performance \\
\cline { 2 - 4 } & $\begin{array}{l}\text { Castedo et al. } \\
2018\end{array}$ & $\begin{array}{l}\text { Learning } \\
\text { involvement }\end{array}$ & $\begin{array}{l}\text { Positively impacted students } \\
\text { learning }\end{array}$ \\
\cline { 2 - 4 } & $\begin{array}{l}\text { Yelamarthi } \\
2016\end{array}$ & $\begin{array}{l}\text { Students learning } \\
\text { Improved students learning }\end{array}$ \\
\cline { 2 - 5 } & Turnbull 2018 & Students learning & Maximize problem solving time \\
\hline
\end{tabular}




\begin{tabular}{|c|c|c|c|}
\hline & & $\begin{array}{l}\text { and } \quad \text { problem } \\
\text { solving }\end{array}$ & and enhanced learning \\
\hline & Aqqal 2017 & $\begin{array}{l}\text { Students learning } \\
\text { and achievement }\end{array}$ & $\begin{array}{l}\text { Impacted students learning and } \\
\text { achievement }\end{array}$ \\
\hline & Gren 2019 & Academic success & Improved students' success \\
\hline & $\begin{array}{l}\text { Mavromihales } \\
2018\end{array}$ & $\begin{array}{l}\text { Learning } \\
\text { experience and } \\
\text { engagement }\end{array}$ & $\begin{array}{l}\text { Enhanced students learning } \\
\text { experiences and engagement }\end{array}$ \\
\hline & Akaslan 2016 & Students learning & $\begin{array}{l}\text { Flipped learning assists students } \\
\text { learning }\end{array}$ \\
\hline Social & $\begin{array}{l}\text { Hussain et al. } \\
2020\end{array}$ & $\begin{array}{l}\text { Grade and } \\
\text { engagement }\end{array}$ & $\begin{array}{l}\text { The approach enhanced students } \\
\text { grades and their engagement } \\
\text { levels }\end{array}$ \\
\hline Personal & Nielsen 2020 & Students learning & $\begin{array}{l}\text { Flipped learning enhanced student } \\
\text { study habits }\end{array}$ \\
\hline & $\begin{array}{l}\text { Clarik et al., } \\
2016\end{array}$ & $\begin{array}{l}\text { Comparing the } \\
\text { study effectiveness }\end{array}$ & $\begin{array}{l}\text { Flipped learning enhanced } \\
\text { students practices skills in } \\
\text { numerical methods course }\end{array}$ \\
\hline & $\begin{array}{l}\text { Baughman } \\
2019\end{array}$ & $\begin{array}{l}\text { Team satisfaction } \\
\text { and } \\
\text { assessment }\end{array}$ & $\begin{array}{l}\text { The results improved team } \\
\text { satisfaction levels and peer } \\
\text { assessment rates. }\end{array}$ \\
\hline Cognitive & $\begin{array}{l}\text { Baytiyeh, } \\
\& \text { Naja, } \\
(2017)\end{array}$ & Learning outcomes & $\begin{array}{l}\text { Enhanced students problem } \\
\text { solving and critical thinking, self- } \\
\text { confidence and teamwork skills. }\end{array}$ \\
\hline & $\begin{array}{l}\text { Clark et al. } \\
2016\end{array}$ & $\begin{array}{l}\text { Engagement and } \\
\text { learning }\end{array}$ & $\begin{array}{l}\text { Flipped learning enhanced } \\
\text { students learning and their class } \\
\text { engagement }\end{array}$ \\
\hline
\end{tabular}

The second research question queries at which education level flipped learning is most frequently used in science education and based on Table 2, many of the flipped learning studies were carried out on the level of bachelor's degree students 15 studies $(93.75 \%)$ and this is followed by one study conducted among master and $\mathrm{PhD}$ students in engineering education $(6.25 \%)$. The objective of flipped learning mode is to boost the students' motivation, explain topics to them and enhance their learning experiences and engagement in their learning activities. Many of the teaching-learning sessions were based on practical instruction and hence, computer-assisted instruction is an effective method that can be availed from by higher education in several academic year. 
Meanwhile, studies that focused on using flipped learning and its benefits among master and $\mathrm{PhD}$ students are still limited and this limitation may be attributed to the hours loads and maturity level as well as bachelor's degree students need more encouragement, and they are less self-direct learners compared with postgraduate students. Therefore, this study makes a call to examine the effectiveness of flipped learning model among master and $\mathrm{PhD}$ students in engineering education field.

Table 2. A Summary of the Sample used in Flipped Learning for Engineering Education

\begin{tabular}{|l|l|l|}
\hline Sample & No. & Percentage \\
\hline Bachelor & 15 & $93.75 \%$ \\
\hline Bachelor, Master and PhD & 1 & $6.25 \%$ \\
\hline
\end{tabular}

The third question queries the advantages, limitations, and challenges of flipped learning mentioned in engineering education studies. However, the use of flipped learning in the field of health education enhanced various learning skills among science students, including their learning outcomes, performance, their attitudes, personal and cognitive skills (Yoon, 2020; Hussain et al., 2020; Gren, 2019; Fung, 2020, Bielsen, 2020; Baughman et al., 2019; Castedo et al., 2018; Jo et al., 2018). Advantages of flipped learning were also mentioned by Nielsen (2020), who stated that educators are enabled to carry out their experiments with the help of flipped learning to reinforce learning of students and changing their study habits. This also was supported by Hussain et al. (2020) who reported that flipped learning approach in the classroom enhances student's engagement with their teachers and peers. Jdaitawi (2020) also reported that flipped learning assist students in engaging in improving their connectedness and foster leisure attitudes. Aside from the above studies, Bielsen (2020), Yoon et al., (2020), Baytiyeh and Naja, (2017) and Aqqal et al. (2017) showed that flipped learning improves the students' learning motivation, their positive interest, behaviors and their learning outcomes, along with their cognitive skills. This finding may be linked to the general premise that technology, with the use of flipped learning model, responds effectively to engineering students. Furthermore, flipped learning plays a key role in improving the social skills and interaction among students and teachers and their motivation (e.g., Hussain et al., 2020). In addition, peer and teacher interactions at its best motivate the students, maximize their engagement, and improve the development of other skills. Finally, it is clear that flipped learning encourages the students to hone their personal skills, social relationships and motivation (Clark et al., 2016; Su \& Chen, 2018).

With regards to the flipped learning technology challenges, majority of the studies (e.g., VanAlten, Phielix, Jansse, \& Kester, 2019; Akcayir \& Akcayir, 2018; Lo et al., 2017) agreed that challenges to flipping the classroom are many and can be individual, institutional, technological or nontechnological (Gardner, 2015). Evaluation process is another limitation (Barral et al., 2018; Nielsen, 2020). Nielsen (2020) stated that students do not have enough focusing on their selfevaluation and self-regulation related to flipped learning, as lacking evaluations related to selfevaluation and metacognition. Another limitation reported in the literature is related to learners, attitude, perception and their learning processes, as students need to be familiar with the flipped learning technique (Peterson, 2016). Flipped learning activities design is a core challenge as its related to the technology being used. Logistics is another challenge in the form of limited resources and time constraints as flipped learning consume more time (Jdaitawi, 2020; Yacout \& AbouShosha, 2016). Technology challenge also reported in the literature as the technical support 
playing crucial role in enabling or limiting the importance of flipped learning (Wells \& Holland, 2015). Length of the videos and time required for students to master the learning materials is another challenge as flipped learning required sufficient technical support to facilitate delivery contents. (Koo et al., 2016; Velegol et al., 2015). Another possible limitation maybe related to the availability of tool to measure flipped learning. Additionally, Finally, flipped learning is a favor technique in those practical knowledge-based courses, as there are many theoretical knowledgebased courses.

\section{Conclusion}

The extensive use of flipped learning only began in the last few decades in providing science information and curricula to engineering students. In this study, the focus is laid on the effectiveness of flipped learning in affecting the outcomes of students in engineering courses. The study carried out a systematic review to determine the use of flipped learning strategy from the perspective of students, highlighting the strengths and weaknesses of approaches, and providing data to comprehend the way flipped learning can minimize the different limitations and challenges that students of engineering courses face when it comes to using flipped learning. The literature review on the use of flipped learning technique showed a total of 16 implementations with the studies agreeing on the positive role of flipped learning technique in engineering courses in different levels (bachelor, master, and $\mathrm{PhD}$ level students). The studies also showed different technologies utilized including computer, laptop, and mobile devices. They revealed that flipped learning mode was successful in enhancing the student's skills and positive learning outcomes.

\section{Limitations and suggestions}

This study has some limitations like other studies, in which the majority of the studies did not examine the influence of students' characteristics, which needs to be examined in future studies. Majority of them also used small-sized samples of participants, and thus, future studies should consider bigger sized samples to validate the findings. Another limitation relates to data collection methods, which future studies should consider, so that they can adopt other approaches. This systematic review presented information concerning ideas and solutions as to how science achievement among students can be improved through flipped learning strategy implemented.

\section{Reference}

[1] Adamson, F., \& Darling-Hammond, L. (2012) Funding disparities and the inequitable distribution of teachers: Evaluating sources and solutions. Education Policy Analysis Archives, 20(37). Retrieved from

http://epaa.asu.edu/ojs/article/view/1053.

[2] Akçayir, G. \& Akçayir, M., 2018. The flipped classroom: A review of its advantages and challenges. Computers \& Education, 126(1), pp. 334-345. https://doi.org/10.1016/j.compedu.2018.07.02 1

[3] Al-Mutawa, A., Jdaitawi, M., Saleh, W., \& Awwad, A. (2014). Psychological strain among academic staff in Eastern Saudi Arabia. Paper presented at the Social Science Conference, Malaysia.

[4] Aqqal, A., Elhannani, A., Haidine, A., \& Dahbi, A. (2017). Improving the teaching of ICT engineering using flipped learning: A personalized model and a case study. Production, 27(spe), e20162274. http:// dx.doi.org/10.1590/0103-6513.227416.

[5] Arksey, H. \& O’Malley, L. (2005). Scoping studies: towards a methodological framework. International Journal of Social Research Methodology, 8(1), 19-32. http://doi.org/10.1080/136455703200011961 6.

[6] Bansal, S., Bansal, M., Ahmad, K., \& Pandey, J. (2020). Effects of a flipped classroom approach on learning outcomes of higher and lower performing medical students: A new insight. Advances in Educational Research and Evaluation, 1(1). Doi:10.25082/AERE.2020.01.005 
[7] Barral, A., Pastores, V., \& Simmons, R. (2018). Student learning in an accelerated introductory biology course is significantly enhanced by a flipped learning environment. CBE-Life Science Education, 17:ar38, 1-9. Doi 10.1187/cbe.17-07-0129.

[8] Baughman, J., Hassall, L., \& Xu, X. (2019). Comparison of student team dynamic between nonflipped and flipped versions of a large-enrolment sophomore design engineering course. Journal Engineering Education, 108: 103-118. Doi: 10.1002/jee.20251.

[9] Baytiyeh, H., \& Naja, M. K. (2017). Students' perceptions of the flipped classroom model in an engineering course: a case study. European Journal of Engineering Education, 42, 1048 - 1061. doi: 10.1080/03043797.2016.1252905.

[10] Bergmann, J. \& Sams, A. (2012). Flip your classroom: reach every student in every class every day. International Society for Technology in Education. 112. Available from: https:// www.iste.org/resources/product?ID=2285.

[11] Brewer, R. \& Movahedazarhouligh, S. (2019). Flipped learning in flipped classrooms: A new pathway to prepare future special educators. Journal of Science Teacher Education.

Doi: 10.1080/21532974.2019.1619110.

[12] Castedo, R., Lopez, L., Chiquito, M., Navarro, J., Cabrera, J., \& Ortega, M. (2018). Flipped classroom-comparative case study in engineering higher education. Computer Application Engineering Education, 27, 206216. Doi: 10.1002/cae.22069.

[13] Clark, R., Kaw, A., \& Sacre, M. (2016). Comparing the effectiveness of blended, semi-flipped, and flipped formats in an engineering numerical methods course. Advances in Engineering Education.

[14] Connor, E., Fried, J., McNulty, N., \& Shah, P. (2019). Flipping radiology education right side up. Academic Radiology, 23(7). Doi: 10.1016/j.acra.2016.02.001.
[15] Davies, R., Dean, D., \& Ball, N. (2013). Flipping the classroom and instructional technology integration in a college-level information systems spreadsheet course. Educational Technology Research and Development, 61(563-580). http://doi.org/10.1007/s11423-013-9305-6.

[16] Eddy, S. L., Converse, M., \& Wenderoth, M. P. (2015). PORTAAL: A classroom observation tool assessing evidence-based teaching practices for active learning in large science, technology, engineering, and mathematics classes. CBE-Life Sciences Education, 14(2), ar23. https://doi.org/ 10.1187/cbe.14-06-0095.

[17] Evans, L., Vanden Bosch, M. L., Harrington, S., Schoofs, N., Coviak, C. (2019). Flipping the classroom in health care higher education: A systematic review. Nurse Educator, 44, 74-78.

doi:10.1097/NNE.0000000000000554.

[18] Fox-Turnbull, W. H., Docherty, P., \& Zaka, P. (2018). Learning engineering through the Flipped Classroom Approach- students' perspectives. Design and Technology Education: An International Journal, 23(3), 27-45.

[19] Fung, C. (2020). How does flipping classroom foster the STEM education: A case study of the FPD model. Technology, Knowledge and Learning, 25, 479-507. http://doi.org/10.1007/s10758-020-09443-9.

[20] Gren, L. (2019). A flipped classroom approach to teaching empirical software engineering. IEEE Transactions on Education.

[21] He Y, Lu J, Huang H, He S, Ma N, Sha Z, et al. (2019) The effects of flipped classrooms on undergraduate pharmaceutical marketing learning: A clustered randomized controlled study. PLoS ONE 14(4), e0214624. https://doi.org/10.1371/journal.pone.0214624

[22] Helgevold, N., \& Moen, V. (2015). The use of flipped classrooms to stimulate students' participations in an academic course in Initial 
Teacher Education. Nordic Journal of Digital Literacy, 10(1), 29-42.

[23] Hussain, S., Jamwal, P., Munir, M., \& Zuyeva, A. (2020). A quasi-qualitative analysis of flipped classroom implementation in an engineering course: From theory to practice. International Journal of Educational Technology in Higher Education, 17(43). http://doi.org/10.1186/s41239-020-00222-1.

[24] Ishak, N., Jdaitawi, M., Ibrahim, Y., \& Mustafa, F. (2011). Moderating effect of gender and age on the relationship between emotional intelligence with social and academic adjustment among first year university students. International Journal of Psychological Studies, 3(1), 78-89.

[25] Ismael, A., Jdaitawi, M., \& Talafha, F. (2015). Towards a better investment of university students in light of the twentieth century challenges. International Educational Studies, 8(6), 113-123.

[26] Jdaitawi, M. (2020). Does flipped learning promote positive emotions in science education? A comparison between traditional and flipped classroom approaches. The Electronic Journal of e-Learning, 18(6), 516524.

[27] Jdaitawi, M. (2020). The effect of using problem-based learning upon students emotions towards larning and levels of communication skills in three different disciplines. Croatian Journal of Education, 22(1), 207-240. http://doi.org/10.15516/cje.v22i13215.

[28] Jdaitawi, M., Al-Mutawa, A., Musallam, F., \& Talafha, F. (2014). Stress and psychological strain among university lecturers in Saudi Arabia. Paper presented at the Global Conference on Business and Finance, 9(1).

[29] Jdaitawi, M. et al. (2013). Students perspectives on university experiences; the role of protective factors in students lives. International Education Studies, 6(7), 239246.
[30] Jo, J., Jun, H., \& Lim, H. (2018). A comparative study on gamification of the flipped classroom in engineering education to enhance the effects of learning. Computer Application Engineering Education, 26, 1626-1640. Doi: 10.1002/cae.21992.

[31] Jose et al., (2020). Effectiveness of flip teaching on engineering student's performance in the physic lab. Computer \& Education, 144, 103708.

[32] Kanelopoulos, J., Papanikolaou, K., \& Zalimidis, P. (2017). Flipping the classroom to increase student's engagement and interaction in a mechanical engineering course on machine design. iJEP, 7(4), 19-34. http://doi.org/10.3991/ijep.v7i4.7427.

[33] Karabulut, A., Cherrez, N., \& Jahren, C. (2017). A systematic review of research on the flipped learning method in engineering education: Flipped learning in engineering education. British Journal of Educational Technology, 49(3). Doi: 10.1111/bjet.12548.

[34] Kitchenham, B. (2004). Procedures for performing systematic reviews. http://citeseerx.ist.psu.edu/viewdoc/summary ?doi=10.1.1.122.3308.

[35] Koo, C. L., Demps, E. L., Farris, C., Bowman, J. D., Panahi, L., \& Boyle, P. (2016). Impact of flipped classroom design on student performance and perceptions in a pharmacotherapy course. American Journal of pharmaceutical education, 80(2), 33.

[36] Lei Zhang, Yueqing Xuan, \& Huimin Zhnag (2020). Construction and application of SPOC-based flipped classroom teaching mode in Installation Engineering Cost curriculum based on OBE concept. Computer Applications in Engineering Education. http://doiorg.library.iau.edu.sa/10.1002/cae.22320.

[37] Lo, C. K., \& Hew, K. F. (2017). A critical review of flipped classroom challenges in $\mathrm{K}$ 12 education: Possible solutions and recommendations for future research. Research and Practice in Technology 
Enhanced Learning, 12(4), 1-22. https://doi.org/10.1186/s41039-016-0044-2.

[38] Lee, J., Lim, C., \& Kim, H. (2017). Development of an instructional design model for flipped learning in higher education. Education Technology Research Development, 65, 427-453. Doi: 10.1007/s11423-016-9502-1.

[39] McLaughlin, J., White, P., Khanova, J. and Yuriev, E., 2016. Flipped classroom implementation: a case report of two higher education institutions in the United States and Australia. Computers in the Schools, 33(1), pp.

24-37.

doi: 10.1080/07380569.2016.1137734.

[40] Male, S. A., Bush, M. B., \& Chapman, E. S. (2011). An Australian study of generic competencies required by engineers. European Journal of Engineering Education, 36(2), 151-163. doi: 10.1080/03043797.2011.569703.

[41] Malek, J. (2015). Social connectedness, academic, non-academic behaviors related to self-regulation among unievristy stduents in Saudi Arabia. Interantional Education Studies, 8(2), 84-100.

[42] Malek, J. (2019). The effect of flipped classroom strategy on students learning outcomes. International Journal of Instruction, 12(3), 665-680.

[43] Maya Panorama., \& Malek, J. (2011). Relationship between emotional intelligence and work-family conflict of university staff in Indonesia. Paper presented at the International Conference on Social Science, Economics and Arts, 14-15 January, Malaysia.

[44] Martínez-Carrascal, J. Cebrián, D., SanchoVinuesa, T., \& Valderrama, E. (2020). Impact of early activity on flipped classroom performance prediction: A case study for a first-year Engineering course. Computer Applications in Engineering Education. http://doi.org/10.1002/cae.22229.

[45] Meier, R. L., Williams, M. R., \& Humphreys, M. A. (2000). Refocusing our efforts: assessing non-technical competency gaps.
Journal of Engineering Education, 89(3), 377-385.

[46] Movromihales, M. \& Holmes, V. (2016). Delivering manufacturing technology and workshop appreciation to engineering undergraduates using the flipped classroom approach. International Journal of Mechanical Engineering Education. http://doi.org.10.1177/0306419016637487.

[47] Nielsen, K. (2020). Students video viewing habits during a flipped classroom course in engineering mathematics. Research in Learning Technology, 28, 2404. http://dx.doi.org/10.25304/rtl.v28.2404.

[48] O'Flaherty, J. \& Phillips, C. (2015). The use of flipped classrooms in higher education: A scoping review. Internet and Higher Education, 25, 85-95.

[49] Peter, M., Khoo, E., Cowie, B., Scott, J., \& Round, H. (2017). Reengineering an engineering course: How flipped classrooms afford transformative teaching, learning, and workplace competency. Teaching \& Learning Research Initiative.

[50] Peterson, D. J. (2016). The flipped classroom improves student achievement and course satisfaction in a statistics course: A quasiexperimental study. Teaching of Psychology,43(1), 10-15.

[51] Persky, A. \& Pollack, G. (2010). Transforming a large-class lecture course to a smaller-group interactive course. American Journal of Pharmaceutical Education, 74(9), 170.

[52] Persky, A. \& Pollack, G. (2011). A modified team-based learning physiology course. Am J Pharm Educ, 75(10).

[53] Peter, M., Khoo, E., Cowie, B., Scott, J., \& Round, H. (2017). Reengineering and engineering course: How flipped classrooms afford transformative teaching, learning and workplace competency. Teaching \& Learning Research Initiative. Retrieved from http://www.tlri.org.nz/sites/default/files/proje cts/TLRI\%20Summary_Peter\%26Khoo.pdf 
[54] Prevalla, B. \& Uzunboylu, H. (2019). Flipped learning in engineering education. TEM Journal, $\quad 8(2), \quad 656-661 . \quad$ Doi: 10.18421/TEM82-46.

[55] Rathner, J. \& Schier, M. (2020). The impact of flipped classroom andragogy on student assessment performance and perception of learning experience in two advanced physiology subjects. Advances in Physiology Education, 44(1). Hhtp://doi.org/10.1152/advan.00125.2019.

[56] Sojayapan, C., and Khlaisang, J., 2018. The effect of a flipped classroom with online group investigation on students' team learning ability. Kasetsart Journal of Social Science. doi:10.1016/j.kjss.2018.02.003.

[57] Su, C. \& Chen, C. (2018). Investigating the effects of flipped learning, student question generation, and instant response technologies on students learning, motivation, attitudes, and engagement: A structural equation modeling. EURASIA Journal of Mathematics, Science and Technology Education, 14(6), 2453-2466.

http://doi.org/10.29333/ejmste/89938.

[58] Thai, N., Wever, B., \& Valcke, M. (2017). The impact of a flipped classroom design on learning performance in higher education: Looking for the best blend of lectures and guiding questions with feedback. Computer \& Education. Doi: 10.1016/j.compedu.218.01.003.

[59] Tutrang, T. \& Schenke, K. (2017). Can flipping the classroom work? Evidence from undergraduate chemistry. International Journal of Teaching and Learning in Higher Education, 29(3), 421-435.

[60] Turnbull, W., Docherty, P., \& Zaka, P. (2018). Learning engineering through the flipped classroom approach students' perspectives. Design and Technology Education: An International Journal, 23(3), 27-45.
[61] Van-Alten, D., Phieix, Janssen, J., \& Kester, L. (2019). Effects of flipped the classroom on learning outcomes and satisfaction: A metaanalysis. Educational Research Review, 28. http://doi.org/10.1016/j.edurev/2019.05.003.

[62] Velegol, S., Zappe, S., \& Mahoney, E. (2015). The evolution of a flipped classroom: Evidence-based recommendations. Advances in Engineering Education, 4(3), 1-37.

[63] Vliet, E., Winnips, J., \& Brouwer, N. (2015). Flipped-class pedagogy enhance student metacognition and collaborative-learning strategies in Higher education, but effect does not persist. CBE Life Science Education, 14(3), 1-10. 10.1187/cbe.14-09-0141.

[64] Water-Perez, N. \& Dong, J. (2012). Flipping the classroom: How to embed inquiry and design projects into a digital engineering lecture. ASEE PSW.

[65] Wells, M. \& Holland, C. (2015). Flipping learning: Challenges in deploying online resources to flipped learning in higher education. Advance in Educational Technologies and Instructional Design (AETID). DOI: 10.4018/978-1-4666-96808.ch001.

[66] Yacout, D. (2016). Nursing students' perceptions towards flipped classroom educational strategy. Journal of American Science, $\quad$ 12(2), 62-75. Doi:10.7537/marsjas12021607.

[67] Yoon, S., Kim, S., \& Kang, M. (2020). Predictive power of grit, professor support for autonomy and learning engagement on perceived achievement within the context of a flipped classroom. Active Learning in Higher Education, 21(3), 233-247. Doi: $10.1177 / 1469787418762463$

[68] Zhang, H., Du, X., Yuan, X., \& Zhang, L. (2020). The effectiveness of the flipped classroom mode on the English pronunciation course. Creative Education, 7(9), 1340-1346. Doi: 10.4236/ce.2016.79139. 